\title{
An Outlook of Each of the Islamic Thought and the Contemporary Global Thought on the Human Concept and Rights
}

\author{
Mohammad Salman AlKhaza'leh \\ College of Education and Social Sciences, \\ Al-Ain University, Abu Dhabi, \\ United Arab Emirates
}

DOI: https://doi.org/10.36941/ajis-2021-0047

Abstract

This study aimed at identifying the view of Islamic thought and the contemporary global thought on the human concept and rights. It also aimed at highlighting the interest of the Islamic and contemporary thinkers in the human rights area and knowing the way both thinkers meet. The researcher applied the theoretical (comparative) method using both the description and analysis. The study concluded the following results: The contemporary Islamic view of the human concept and rights covered all types of rights, such as freedom of belief and thought, education, right to live, personal freedom, protection of property and honor, child rights, the woman, equality before the law; and fight against the racial discrimination. The study further showed the emergence of originality and independence in the rights and freedoms in Islamic thought and the balance in legislation. On the other hand, the study underscored the convergences of both the Islamic and global thought in the human rights field that emerged in the Islamic Declaration of the Human Rights in 1990. This declaration emphasized the contribution of mankind's efforts that are related to human rights, which aim at protecting the human against exploitation and persecution and ensure his freedom and right to a decent life. All these provisions and principles are in agreement with the Islamic Sharia (law), which indicates that many of these principles are deeply rooted in Islamic thought. The study also emphasized that human rights in global thought are of great importance, at the level of peoples, states, and international organizations. The Universal Declaration of Human Rights, which was issued by the General Assembly of the United Nations on Dec. 10, 1948, is a culmination of the Western civilization and the efforts of the thinkers and reformers in it. The declaration provided that "forgetting" or neglect of human rights led to barbaric acts that hurt the human conscience.

Keywords: Human concept, human rights, Islamic thought, global thought

\section{Introduction}

Human rights are a modern term for an ancient fact that is associated with the human since the creation beginning. The heavenly religions and the different intellectual and philosophical trends paid attention to these rights, and they gained particular sanctity in our age, especially among the international organizations. As a result, the rights were recorded in statutes, declarations, or statutory laws in various modern political systems. In this concern, the Islamic Sharia (law) has the entrepreneurship in asserting these rights and conducting all forms of justice, which deal in the individual, the community, and the state. The right was the foundation for building the Islamic system. 
Islam recognizes the equality principle among people in the common human values, as Islam considered people equal in their human nature, and there is no preferred group over another based on its human element, first creation, or being descendant of a certain lineage. Rather, the preference among people is based on other matters that are beyond their nature, elements, races, or first creation. It is built on their cooperation incompetence, science, ethics, and businesses.

Islamic education has been very keen to establish this equality in its fullest form and made it of the basic beliefs that every Muslim must hold. It further took it as a base for all whatever the communities enacted of legislations, and what it granted of rights to the human. In this concern, Almighty Allah says: "O, people! We created you from a male and a female, and We made you races and tribes, so that you may come to know one another. The best among you before Allah is the most righteous. Allah is Knowing and Aware." (Holy Quran, Surah Al Hujurat, Verse 13). This means that you (the peoples) are descendants of one father and one mother; none of you has the preference over the other based on his race or nature. If Allah made you races and tribes, He did not make you so to prefer a people over another, nor a tribe over another, but He divided you in this manner to make this division a means of cooperation and prominence, the way the individuals are, everyone has a name to be known with, and to be distinguished from all other persons. In the "Eyes of Allah", the moralists of you are based on your deeds and the extent of your adherence to the orders and rules of your religion; so the best of you is the most piteous and righteous (Al-Wafi, 2006). The human dignity provides the individual many established rights such as: right of Allah and His Prophet (Peace and Blessings of Allah be upon Him "PBAUH"), right of decent life and preserving the self, right of owning and gaining; right of the parents, right of the offspring, right of the relatives, right of the spouses, right of birth and care, right of the neighbors, and right of all the Muslims and non-Muslims (Yousuf, 2009).

The Messenger of Allah (PBUH) addressed the people saying: "O people, your God is one, your father is one, you are all offspring of Adam, and Adam was created of clay, no Arabian has preference over non-Arabian, nor any non-Arabian over Arabian, nor a red person over a white, nor a white over a red has a preference, except in the degree of piety (Al-Hafeth, 1979).

From the above, one can very clearly see this great advancement that Islam made and is rooted in the history of the social systems. Islam implemented the stipulated orders and rules regarding equality among people in the common human value, which is deemed a very important advantage of Islam over all that was prevailing in the former nations and legislations, where many types of racial discriminations and the like were practiced. As a result, Islam established the relations between people based on a one decent family concept (Atiyyah, 2008).

As for global thought, the human rights principles recently gained international attention by many of the officials of the developed, advanced, and developing countries. These rights occupied a prominent place in the educational curricula, media, and among people. Principles of human rights contributed, to a wide extent, to preserve many of the human values in the contemporary world. Due to their significance, many institutes, colleges, centers, and specialized institutions were created to these principles (Kashkash, 1987). All these made people strongly hold aspirations and ambitions in the results of these principles, which made them more urgent in the age we live, the age that is full of tragedies and pains. Hence the need arose to defend the deprived, the needy, and the vulnerable on earth, to save them from the torment of the arrogant people, the wrongdoers on earth, to protect them from evils, and to be with them in times of calamities and disasters.

Humanitarian intervention in the light of the international contemporary law has many types and forms, as it is every intervention that aims at protecting human rights and their fundamental freedoms. It could be a military or diplomatic intervention that includes all the nationals and foreigners. Besides, there are the contemporary humanitarian interventions that could be carried out by a state or some states, an international, global, or regional organization, within the framework of the United Nations Organization (Al-Khazaleh, 2012). Some considered this intervention a "right" if it comes to securing a passage to reach the victims; and a "must" if the humanitarian intervention seeks to respect the basic rights of the individual, such as the right of life. However, this intervention is not always humanitarian most of the time and maybe "coated" with economic and military motives. 
It is noted that those who talk about human rights start from different ideological standings. They are either democratic, the way they are in the liberal systems that choose their principles from pragmatic, materialistic, and utilitarian, earthly philosophy. Or else, as in the socialist countries that choose their principles from a socialist philosophy and totalitarian, communist systems. All these systems determine their relations with the human being in so far as much as they serve his purposes and achieve the missions of these systems (Mohammad, 2004).

\section{$1.1 \quad$ Previous Studies}

The researcher reviewed the studies that dealt with the human rights issue, such as:

Al-Khaza'aleh's Study (2019), "Human Rights in Islam", in which he used the analytical method. Its results emphasized that human rights are maintained and preserved in the Islamic thought, and are corroborated by the Hadith (sayings) of the Messenger of Allah (PBUH), "The human is respected because of his humanity, he is of the children of Adam, you must respect him, even if he is different from you in race and religion."

Al-Sharafi's study (2018) aimed to identify the reality of education about human rights. The researcher prepared four questionnaires sent to the ministries of education in twenty-one Arab countries, (200) higher education institutions, and (50) Arab NGOs. The study made important results, such as the absence of an Arab strategy in the education field about human rights, and the absence of legislation related to education about human rights.

Charles made a study cited in Agha (2003), aimed at identifying the relationship between civic education, press, and human rights in democratic behavior. The study was conducted in the United States of America, and the researcher applied the experimental method on a sample that comprised (648) participants. The researcher concluded that there is a direct, positive relationship between the individuals' behaviors and their ability to control their positive behavior. He recommended the necessity to teach citizenship and civic education in the preschool stage because they affect the individual's life. He also recommended looking at them as an ongoing learning experience, and that the individual should be taught that his rights are obtained through democracy only.

The study of Qaqeesh (2005) aimed at assisting the male and female teachers in explaining the principles of the human rights that were included in the universal declaration; and helping them the link between the activity and the prescribed curriculum by providing a suitable classroom environment, discussion, dialogue, role play, and story.

Wade (2011) made a study that aimed at designing a curriculum of the human rights for the fourth graders in public schools, through practicing democracy in the classrooms. The study concluded that the students' personal experience, level of growth, level of family, and cultural background strongly affected the students' thoughts in interests, and hence on learning the human rights. Furthermore, the use of democracy in the classrooms gave many students opportunities for better teaching.

Al-Jarbawi (2001) conducted a study that aimed to illustrate that teaching human rights is not traditional education. The study found two axes to introduce human rights education to schools, one is based on allocating specific classes to teach them in isolation of other subjects, and the second is based on integrating it with other subjects.

Wafi (2008) conducted a study aimed at identifying the perception of human rights in Islam. He concluded that the Islamic Sharia (law) preceded all other legislations in affirming human rights; that the Islamic nations in the era of the Messenger (PBUH) and the rightly guided caliphs, who came after Him, were the earliest nations to apply these rights; and that the modern democratic states themselves, in the present times, are still far lagging behind the Islamic system.

The study of human rights in Islamic thought is a very significant and necessary issue, to demonstrate the glorious role of Islam and its Sharia (law) to maintain, preserve and protect these rights. The significance of this type of study increases due to the increasing complications in international and humanitarian relations. The world is living an ethical crisis in the light of conditions where many of the human rights and freedoms are breached throughout the whole world. Besides, the 
views about human rights differed among the theorists, each took them the way he deems (AlMotawakkil, 2005).

\subsection{Study Problem}

The study problem is defined by the main following question: "What is the image of the human rights in both the Islamic thought and the Western contemporary thought?" The following questions branched from the main question:

What are the most important basic human rights that Islamic thought called for?

What is the image of human rights in contemporary global thought in the light of the universal documents of human rights?

What are the comparison aspects between the outlook of human rights in both the Islamic and contemporary global thoughts?

\subsection{Significance of Study}

The significance of this study arises from explaining that Islam is the human rights religion, and the superb texts of the Holy Quran and Sublime Tradition (Sunnah) are a great constitution of all the human rights throughout all his different life stages. It also illustrates that Islam preceded the contemporary positive universal legislations, documents, and international deeds that called for human rights. The significance further stems from demonstrating the bright image of Islam with all its contents of virtuous morals, wise teachings, and ethical guides, as well as from spotting the lights on the contemporary constitutions and charters in terms of human rights.

This study seeks to achieve the following objectives:

To Identify the most important human rights the Islamic thought called for.

Exposing the image of human rights in contemporary global thought.

Demonstrating the originality and contemporary aspects in the outlook of human rights in both the Islamic and contemporary global thoughts.

\subsection{Terminology}

Human rights: is the group of rules and demands that should be fulfilled for all humans equally, without any discrimination among them. These rights have peremptory norms, as the global dealing is established on that these norms are binding even if some countries did not accept them, as they regulate serious and very important affairs in maintaining the international community.

The Islamic thought: the thought that expresses the efforts of the human mind to interpret human rights in the framework of the Islamic principles, in terms of the doctrine, Sharia, and behavior.

The Western contemporary thought: is a group of positive legislative thoughts produced by ideas, theories, laws, and charters of the stakeholders in the contemporary West of numbers of countries or the thought of scientists.

\subsection{Method}

This study is one of the specific studies that employed the descriptive, analytical, comparative method, depending on analysis, description, and comparison to extract the image of human rights in both the Islamic and contemporary global thoughts. 


\section{Discussion}

\subsection{First: the basic human rights in the Islamic educational thought}

Freedom of the religious belief in Islam. The human in the Islamic state enjoys the freedom of doctrine and religion. He has the absolute freedom to choose the religion that fits him. Islam refused the logic of violence, oppression, and coercion. No doctrine accepts these mischievous things, nor implants them in any self. In addition, the belief that comes through them is of no value, and its holder has no dignity because it was not the result of intellectual conviction and mental awareness. Al-Tabari narrated on the authority of Ibn Abbas that a man from Salem Bin Awf's tribe named "Al-Husain" was Muslim and his parents were Christian. He came to the Messenger (PBUH) and asked him whether he is legally allowed to coerce them to embrace Islam while they refuse any religion other than Christianity. The Messenger (PBUH) ordered him not to do so (Al-Farhan, 2001).

The Muslims maintained this principle to the farthest extent in their dealings with the peoples of the countries and territories that they were subject to their regime. They recorded it very clearly in all what they held of treaties. In this concern, Omar Bin Al-Khattab (May Allah be pleased with him), says in the treaty he held with the people of Bait Al-Maqdis (Jerusalem) after he opened it: "This is what Omar Bin Al-Khattab gave to the people of Ilia'a (One of the names given to Jerusalem throughout history) of security; he (Omar) gave them security on their selves, churches, and crosses; they will not be coerced to convert nor any of them will be hurt or harmed" (Al-Shishani, 1998).

Freedom of thought and thinking: with the same attention that Islam showed toward the human body, at the same time, it was keen on his mind and thought far from any restrictions that limit his launch, and prevent his thinking, contemplation, and reflection. Moreover, it urged and stressed that the mind and intellect should be free wanders in the creation of the heavens and earth, deeply thinking of and understanding them. He recognizes the signs of Allah that strengthen his belief in Allah, which will become a leading way to know his Creator, Allah, the only one to worship. Allah, the Exalted said: "Those who remember Allah while standing, sitting, and lying on their sides; and they reflect upon the creation of the heavens and the earth: "Our Lord, you did not create this in vain. Glory be to You! So protect us from the suffering of the Fire" (Al-Marzouqi, 2005).

Islam, through urging the human to think, recognizes to him something of his human nature and one of his human characteristics. But, at the same time, directs him to utilize this intellectual activity the way that benefits him and his community, without causing any harm to others of his race, in the application of the great rule of Islam, "Do not harm others, nor are you to be harmed by others" (AlDoghmi, 1984). The Messenger of Allah (PBUH) followed this noble principle and the guided Caliphs followed it after Him. The freedom of opinion was guaranteed throughout their times and maintained by a fence of holiness. With the stability of the history of this "golden" era, which very truly represents the principles of Islam, we did not find any attempt from the rulers or governors to restrict the opinion freedom. In this concern, the opinion freedom also includes what is called the scientific freedom or freedom of scientific thinking, which means that everybody has the right to decide what he deems fit concerning the phenomena of astronomy, nature, plant, animals, and mankind, believe in what his mind guides to and is persuaded of its authenticity of theories, and to express his opinion through the multiple ways of expression (Salem, 200o). One of the aspects of thought liberation in Islam is its urging and encouraging seeking knowledge, as the intellect is the tool of science and knowledge. Thus, Islam emphasized seeking knowledge and science, and Allah, the Exalted revealed the first verse of the Quran to His Gracious Prophet asking Him to read. Allah, the Exalted said: "Read, in the name of your Lord, who created" (Al-Alaq Surah, Verse 1). Reading and writing are the main tools of knowledge and science that reveal the components of thought and science and unleash its owner to contemplate the greatness of the creation of Allah in the earth and heavens. The Prophet (PBUH) said "Seeking knowledge is an obligation for every male and female Muslim (Al-Bukhari authenticated it in the Book of Blood Moneys, No. 6878).

Freedom of work in Islam: work in Islam is the life way, the universe rule, and the way of 
happiness in life and the hereafter. Islam urged work, endeavor, activity, and movement so that the Sunnah of urbanism makes its way in ease, flexibility, and clarity. Work in Islam is based on two extremely important conditions: the first is that the work should be legal (Sharia), fruitful, benefiting, i.e. not causing harm to the worker or the others. The second is that this work should suffice the worker and keep him away from the need for others, and make him able to support himself and his dependents. Therefore, Islam, in harmony with these elements that it calls to achieve, urges people to the freedom of gaining in two ways: the first: it forbade asking others (begging), and the second: it urged people and encouraged them to work. Islamic education did not isolate seeking science from work, or the theory from the application. It called for a new complementarity of the individual personality through the advanced doctrinal education, which resulted in great advancements in sciences, arts, and literature in the first Islamic world by the positive influence of the spirit of Islam that calls for research and experimentation. Building on this sacred view of work, Islam sanctifies the right of the worker in the "fruits" of his work and ownership of his wages. It calls to the fulfillment of the worker's pay and warns those who practice injustice on the workers with war from Allah and His Messenger. In this connection, the Messenger (PBUH) says in the Qudsi Hadith where he narrates from His Lord: Allah, the Exalted said: "Three people with whom I shall be their litigant on the Day of Resurrection, and He mentioned of them a man (employer) who hired a person who perfectly performed his work, and he (the employer) did not give him his wage." Islam also calls for paying the wage as soon as possible. In the same issue, the Messenger of Allah (PBUH) says: "Give the worker his pay before his sweat dries away." In the issue of the woman's work, Messenger of Allah encouraged the women to learn the crafts that fit their characteristics and functions as mothers and wives (Al-Shatibi, 1980).

The researcher notes from the above examples that the Islamic Sharia encouraged professional work and paid great attention to it. There are many proofs and pieces of evidence that urged people to take the manual and professional works, which expressed a high humanitarian perception of earnings and work concepts, stemming from a deep awareness that earnings and work are equal to life.

Freedom of learning and culture in Islam: the human has his physical and moral entity, and when he is born, he is a weak-bodied baby with very low thinking abilities. Allah, the Exalted said: "And Allah brought you out of your mothers' embryos, you know nothing, and made for you hearing, vision and hearts, so that you may be thankful." (Surah Al-Nahl, Verse 78) As preserving the material entity of the human is his basic rights, preserving his moral right is equally of his basic rights, for which learning is the way to achieve, as learning is one of the components of the human's cultural personality; and the higher the human's culture, the higher his moral entity is. Islam gave everybody the right to obtain knowledge, science, and culture the amount he wishes, as per his abilities, conditions, and readiness. It made this an obligation on the human within the acceptable limits of his religion and life affairs. In this regard, the Messenger (PBUH) says: "Seeking knowledge (science) is an obligation on every male and female Muslim." The Islamic world enjoyed a cultural unity, for which all the means of nourishment were provided, even in the ages of apparent political divisions. At that time, the Islamic world did not know the "artificial" borders that restrict the freedom of movement within the countries of Islam. The scholar, scientist, student, and book were moving very freely within the great area that extended from the shores of the Atlantic Ocean until central Asia, which led to the unity of the cultural and practical movement in terms of the basis and constituents, as well as in many common features.

Therefore, the scientific relations throughout the Islamic world were very firm and strong enough, which provided the scientific life growth, development, and prosperity; added to it a holistic view, benefited from the experiences and efforts of the scientist and learner, wherever they are. The teachers taught the Europeans the highest humanitarian trait that the humans should hold, i.e. the religious tolerance trait, and the European references and documents unanimously agreed that the Christians and Jews, during the Islamic rule in Andalusia, enjoyed a degree of tolerance the like of which is not found even in the contemporary European countries. They were left free to perform their religious rituals and kept their churches and temples, even Andalusia employed many of the Christians, and some of them ranked senior positions in the state. In this concern, a fair European researcher such as Le Bon could not help but admitting very clearly the effect of Muslims on European ethics and natures. 
He said: "The Europeans got rid of their savageness thanks to their contact with Muslims, and borrowed from them noble natures and chivalry principles, of which are: observing women, elderly, and children, respect of covenants and fulfillment of the promises." Then he comments on this by questioning: "Why then the scholars of our times, who rank the thought freedom principle over any religious consideration, deny the influence of Muslims? I find only one answer for this question, which is that our intellectual independence was only in the phenomena and that we are not thought-free in certain issues. Some virtuous people believe that it is a shame to accept the idea that Europe is indebted in getting rid of the barbarism role to the Muslims, but it is quite difficult that this false shame will mask the face of facts (Al-Mufti and Al-Wakeel, 1992).

Right of life: Islam stressed the need to respect the human soul, and prohibited killing among all humans, young, old, men, women, Muslims, or non-Muslims. Islam considered the illegal killing of one person as the killing of all the humans of the world. Allah, the Exalted, said: "That whoever kills a person-unless it is for murder or corruption on earth—is as if he killed the whole of humankind; and whoever saves it, is as if he saved the whole of humankind". This means that Islam absolutely respects human life, respects human rights regardless of whom this human is; ordained the retribution punishment to save this life, notwithstanding the race, gender, age, status, or religion of the murdered. The Islamic Sharia constitutes, in addition to the retribution punishment is premeditated murder, otherworldly punishments, such as depriving the murderer of inheritance. Even Islam does not stop at the end of all these worldly punishments but threatens the killer with the wrath and damn of Allah, as well as the severest punishment in the hereafter (Al-Janabi, 2015).

Right of the personal freedom: Islam, through its orders and prohibitions, has been keen that the Muslim should be free, servant (slave) of no one except Allah, so that his self and soul are led by the only One, Allah. What further enhances the attitude of Islam toward preserving the individual's freedom is equality among all people, and the criterion of differentiation is piety. Allah, the Exalted says: "O, people! Be conscious of your Lord, who created you from a single soul, and created its mate from it, and propagated from them countless men and women." (|Surah Al-Nisa'a, Verse 1). There is an abundance of pieces of evidence in Islamic history that indicate the equality between the governors, sultans, kings, and their children of the public and simple people. They sat in the judicature councils with the public and the simple people, as the Islamic rule in personal freedom is: "How do you enslave people whose mothers born them free?" Islam fought slavery of all its different, direct kinds through buying and selling the human; and indirect through slavery by guiding, leading, humiliation, colonization, and controlling his destiny. Islam fought both its individual and collective types, and called for liberating individuals, as well as liberating the Muslim group to be free, with its decision is in its hands, to enable the individual to rise and regain his human level, and the group to rise and regain its dignity. When Islam called for this, we surely know that Islam has not any purpose other than maintaining humanity from descending anew, and the human falling and worshiping his brother mankind. By this, no one will excommunicate another, and no one will hurt another in his humanity; and hence, the community will be humanitarian, every person feels reassured and comfortable in his relationship with others (Mahmoud, 1997).

Property protection in Islam: Islam surrounded the personal property with a strong fence of protection, and imposed severe punishments on whoever assaults them, whatsoever this aggression was. Islam stipulated the hand amputation punishment for theft, and Allah in this regard said: "As for the male thief and the female thief, cut their hands as a penalty for what they have reaped-a deterrent from Allah. Allah is Mighty and Wise" (Surah Al-Maeda, Verse 38). This punishment is only for what is termed by the Islamic jurists as "minor theft". But in the case of waylaying or highway robbery "major theft" or banditry, the penalty is far higher than hand amputation. For the sake of protecting the ownership, Islam allows the owner to defend his money, property, and the like with all means of defense, building on the saying of the Messenger (PBUH), "Whoever dies fighting to defend his property is a martyr" (Al-Hashimi, 200o).

Islam protection of honor: Islam provided the honor of people with one of the strongest protections which it gave to human rights. The clearer protection is what is seen in the severe judicial 
punishments it inflicts in cases of adultery, indecent assault, and defamation; and in prohibiting backbiting and gossiping. Islam has categorically prohibited spying, whispering, mockery and calling out ugly titles, and so on of everything that affects the honor, reputation, and dignity of a person; despises the committers of these sins, and promises them a painful punishment on the Day of Resurrection (Oudeh, 1987).

Children's right in Islam: Islam provided all care, attention, and education for all children regardless of the difference in gender, religion, color, age, or social class, taking into account that children should be well prepared and trained to enable them to rise with the responsibilities of their nation in future. The rights of children in Islam are obligatory on their parents by choosing the right to parentage, the right to name, the right to breastfeed, the right to a nursery, and the right to a proper upbringing, which is among the great responsibilities assigned to parents toward their children, including good disciplining and providing them perfect and virtuous education. The Prophet (PBUH) said: "All of you are care providers, guardians, and responsible for your folk." One of the best education means is for parents to be good examples for their children in terms of morals, behavior, and dealings because the child imitates his father. Good education in Islam for the child is teaching him the teachings of his rightful religion, such as teaching him the Holy Quran and Sunnah of the Prophet (PBUH). No matter the teaching is theoretical or practical: theoretical, such as writing and reading, and practical, such as the teachings of the Prophet (PBUH): "Teach your children archery, swimming and horse riding." Islam further ordered the parents to allow the freedom of expression and opinion about any question posed by the child, as children frequently ask questions in the beginnings of their lives. The parents and educators are required to answer the child about all that he asks, not to prevent, rebuke, or deny him (Alwan, 1995).

Right of women: Islam looked at the woman through a vision that she was never given to her before or after Islam, the view that was built on the realities of the instincts of the woman nature. The gist of this vision is that the spouses in Islam are humanly equal and in terms of their relationship with Allah, the Exalted, and His rewards for both of them. Thereby, the inferior view about the woman that she is lower than the man disappeared; even more, this improper vision made her of a lower gender. Islam ordered more than this when it decides the unity of the two genders and the unity of the spouses. The view of Islam to the woman education stems from her importance with the above-mentioned terms so that it educates her to build generations and serve the whole human race. Hence, her education was a must and obligation same as the man. She performs the upbringing and early education of her children, based on her belief that children grow up with normal adult health, namely fathers and mothers, in a quiet and meek home for a mother who believes in her God. The above statements show that the woman has a great portion of education in Islam. Many women asked the Prophet (PBUH) to allocate a day for them to be more knowledgeable in the religious matters, and said to Him (PBUH): "Men learn and benefit from you more than us, so allocate a day to us from yourself." He promised them a day to meet, preach and order them." Still, many other rights in Islam were never guaranteed in any other religion, such as human equality, inheritance, trust, dowry, good education, freedom of speech, and right to testify. With all these rights and freedoms, the woman can live in dignity, honor, appreciation, and sacredness within her feminine entity and her nature that Almighty Allah created her in, and within her functions which are based on her biological, physiological, and psychological composition (Abdel Qader, 2017).

General rights of the non-Muslims: (Here jurisprudents differentiated between "Thimmi" who believes in other religion, and "Musta'min", who is in the Muslim country seeking refuge and security"). Non-Muslims in the Islamic state were granted many rights, and even the state increased its respect and appreciation to them, in compliance with the jurisprudential rule "They have rights as ours and obligations as ours", all in terms of the community system and the rights of citizens in it. Among the too many rights, Islam preserved for non-Muslims is that Islam guaranteed and maintained to them keeping their selves, property, and honor in safety and security. This stress on their rights is because some of the Islamic jurists deemed the injustice of the non-Muslim (Thimmi) is more severe than the injustice of the Muslim. Islam emphasized calling them nicely and guaranteed the right to hold 
governmental positions, right to travel and reside good dealing, social security, and sponsorship, right to education and thought, and protection from assault (Al-Shishani, 1980).

The above leads us to conclude that Islamic Sharia (law), around fourteen centuries ago before the emergence of the document of the Universal Declaration of Human rights, stipulated these rights in the fullest form and widest system; that the Islamic nation, in the era of the Messenger (PBUH) and His successor of the rightly guided Caliphs, preceded all other nations in applying these rights; and that the modern democratic states in our ages are still lagging behind the Islamic system in this regard.

\subsection{Second: Human Rights in the Contemporary Global Thought}

In the light of the global documents of human rights, the scholars of the global constitutional jurisprudence assert that the idea of human rights is the common asset and source from which the philosophical schools in the eighteenth century were derived. It is the product of the "school of the natural right" as provided by philosopher John Locke in juristic terms, and later by the English jurist, Blackstone, in the mid-eighteenth century.

Contemporary Western thought seeks to theorize abstract rules and concepts of human rights, upon which it is based to limit the powers of the ruler and recognize the individuals' rights that are derived from the natural law. Or else from the higher reference of the rights and duties, which derives from nature, and the human knows it through reason. In this concern, it is clear that human rights are based on natural rights, and the theorists of communism are not more different from the Western; they differ only in non-linking human rights with individual freedom. The capitalist ideology sees an inevitable correlation between the idea of natural and individual rights, and that linking between the natural law and natural rights that aim at establishing a clear Western rule, i.e. protection of human rights (Al-Baker, 2007).

Human rights in the pragmatic philosophy have been associated with the trend based on utility that emerged from the capitalist system. This system raises the value of private property, achieving profits and increasing the capital, and at the same time, the basic source this philosophy is derived from is the Christian religion. As for the communist systems, the human rights emerged from the communist ideology that Marx, Lenin, and Stalin called for, which raised the public property value, and the human rights were based on social integration. The tragic condition the world experienced in the last century of wars and the associated violations of human rights, such as killing, displacement, hunger, and rape, motivated the nations to sign agreements, declarations, and charters that aim at respecting the human and maintaining his rights. The most important of these were: the Universal Declaration of Human Rights (1948), the International Covenant on the Economic, Social and Cultural Rights (1966), and the International Covenant on the Political and Civilian Rights (1966). All these documents emphasized the equality among people in dignity and the different rights, such as the right of life. The researcher here below briefly introduces the most important rights and freedoms that are contained in the international documents, as may be required by the nature of the study.

The Universal Declaration of Human Rights (1948): included emphasis that all humans are born free, and are equal in dignity and rights; that no whatsoever discrimination should be practiced against them for whatsoever reason; and that they have the right to life, freedom, and security. The Declaration prohibited slavery, servitude, slave trade, torture, and humiliation practices; gave to everybody the personal and legal rights, right of equality before the law; and the right of everybody to recourse to the courts of his country if his rights are violated. It further gave the individual the right of personal freedom and enjoying the nationality, leaving his country and returning to it, as well as the right of the man and woman to form a family. Also, it emphasized the right of property, expressing the opinion, thought, and feelings, and granted the individual the right to participate in public affairs, work, decent life, and that education is available for everyone (Abdel Kareem, 2004).

The International Covenant on the Economic, Social and Cultural Rights (1966): this covenant came to enhance welfare, achieve a dignified life for the peoples, and maintain their cultural, economic, and social interests. The covenant, in addition to the international covenant concerning the civilian 
and political rights, posed a specific shift of the international community in terms of endorsing more rights and freedoms of the humans, such as stress on the right to self-determination and their right to enjoy wealth, goodness and natural materials. It also emphasized the need to secure the economic, social, and cultural rights for both men and women without discrimination, and the need to ensure providing suitable health and social environment that guarantees prevention of infectious and breakouts diseases, and facilitating education and making it available to all; and the need to provide the suitable cultural life and freedom atmospheres for the scientific research (Gazamel, 2009).

The International Covenant on the Civil and Political Rights (1966): this covenant emerged from the Universal Declaration on Human rights to enhance and protect civil and political rights, which are the base of the family and welfare. This covenant emphasized the right to life and perfect equality without any discrimination for color, race, language, gender, doctrine, or origin. It further emphasized prohibiting slavery, slave trade, servitude, full equality between all people before judicature and courts, and the rights of the minorities to enjoin their culture, religions, and mother tongues (Al-Basheer, 2006).

Specific international agreements, charters, and declarations: the Universal Declaration of the Human Rights and the International Covenant on the Economic, Social, Cultural, Civil and Political rights gave rise to many special agreements, charters, and declarations; the most important are the following:

A- Conventions against torture: torture is a non-humanitarian phenomenon, and humanity witnesses a struggle to prevent torture and cruel, a non-humanitarian treatment that degrades the human's status and dignity. Article (5) of the Universal Declaration on Human Rights provided the prohibition of subjecting any person to torture. This document was recognized in (1984), which prohibited all types of torture without any exception (Kilani, 2003).

B- Women and Child Rights Agreements: according to this agreement, which implementation began in (1990), many rights were recognized for both the women and children: the right to life, right to enjoy the name since birth, right to acquire a nationality, right to have care by parents, right to grant them the identity and non-depriving from parents; right to the opinion expressed, right to freedom of thought, emotions, and religion. Besides, the agreement emphasized the rights of disabled children, and the convention on the elimination of all types of violence and discrimination against the woman, "CEDAW" in 1981, which gave her many rights. The most important were: the political rights, such as the right to nomination and voting, right to occupational and professional education, right to health care, right to obtain socio-economic benefits, and right of giving her equal legal eligibility before the courts as that of the man. The agreement also contained the confidential rights of the woman, such as the right to choose the husband, have children, and guardianship of the children (Sultan and Mujahed, 2008).

C- Covenants against racial discrimination: many covenants were recognized to prevent racial discrimination and differentiation, such as the Convention of the Prevention of Genocide (1973), Elimination of All Forms of Intellectual Discrimination (1963), the International Agreement to Prevent the Apartheid Crime (1973), the Special Declaration on Rational Discrimination (1978), the Declaration on the Rights of Persons Belonging to National, Religious or Language Minorities (1992), and Covenant on the Prevention of Discrimination in Education, which was issued by Unesco in 1960. Despite this great amount of agreements, declarations, and covenants, yet most of the minorities around the world are subject to persecution, deprivation, and discrimination. Many of these minorities are still fighting to obtain their legitimate human rights as human beings, which required these covenants to put in actual practical efforts to observe the minorities' rights and discrimination against them (Al-Faqi and Embabi, 2009).

D- Refugee Protection Agreements: the need emerged to hold agreements that protect the refugees due to the constant increase of their numbers because of the conditions that force them to leave their lands and countries. Therefore, UNRWA was established to rehabilitate 
the refugees, as well as the Charter on the Status of Refugees in 1951, and the Charter of the African Unity Organization (Nu'man, 2018).

E- Agreements on the Workers' Rights and Freedoms: The Global Declaration and the two International Covenants emphasized the right of work for everybody, this right was followed by signing many agreements and declarations that included applying this right on the ground. Such as, the agreement to guarantee the right to organize the work, the work conditions, and employment in the public sector (1979) and the international agreement on the protection rights of the workers and migrants and their families in 1990 (Basyouni, 2003).

The above indicates a large number of charters, declarations, and covenants that call for human rights. Even though, who observes the tracks of the human rights in the world recognizes that the human is still suffering from deprivation of his rights. These rights include the right to life, which is the utmost valuable right, as hundreds of innocents die daily, under different pretenses and various claims with many titles (which "justify" killing) such as safeguarding the national security, respect of law, the primacy of the democratic values, peace and security keeping, and the like of titles and arguments that the human pays for.

The human rights that the world is fighting for nowadays are the products of the teachings of the heavenly religions, particularly Islam that called to respect the human rights and freedoms as a human, regardless of his color, gender, or faith. In this connection, Messenger (PBUH) taught humanity, when he told us that "The human should be respected being of Adam proliferation, even if he is different from you in religion, race or gender."

2.3 Third: Comparison aspects between the perception of human rights in Islamic thought and the contemporary global thought

According to the talk about the human concept and rights in Islamic thought and the contemporary global thought, the researcher highlights the following:

First: prominence of the originality and independence in the rights and freedoms in the Islamic thought, because their source is one, which is the fruit of a distinguished, independent doctrine. Therefore, all these are of the Islamic thought production, as well as what branched off it, as the rights and freedoms in them have no non-Islamic roots that may be borrowed from here and there of capitalist or communist system.

Second: balance in the rights and freedoms legislations in the Islamic thought. This is because this thought is based on moderation and justice, and what emphasizes this fact is the clear difference between contemporary capitalist thought and communist thought, which resulted in problems that caused the sufferings of many nations. This required reviewing the teaching and paraphrasing the principles and foundations on which this thought was based.

Third: stability of the rights and freedoms legislations in the Islamic thought. Islam based the provided rights and freedoms on firm standards that do not accept tweaking by the change of circumstances. These rights always maintain their validity and authenticity in all conditions and times, because they are the all true, tight legislations from Almighty Allah, the Exalted.

Fourth: Islamic thought recognized human rights in the fullest shape and widest extent since fourteen centuries, before the appearance of the Universal Declaration of the Human Rights document; thus it was the precedent. On the other hand, the contemporary democracy itself in the present times is still lagging in this issue behind Islamic thought.

Fifth: the contemporary global thought sought to assure, very clearly, the human right to life, freedom, work, education, opinion, expressions, property, enjoying the nationality, fair trial, intellectual and cultural life, freedom of movement, residency, and belief, and right to the prevention of torture, displacement, and banishment. But, despite the endorsement of the Universal Declaration of the Human rights, and the tremendous development in the communication, transportation and advanced technology nowadays, the human is still suffering and complaining from injustice, arbitrariness, violation, torture, displacement, hunger, disease and rape. 
Finally, the Islamic Sharia (Law) continues to be the foundation and source of the right, its support, and the guarantee of its existence and maintaining it in the community. Each of the Islamic International Statement of the Human Rights which was issued in the headquarters of UNESCO, Paris, in 1981, and the Islamic Declaration of the Human Rights issued by the Islamic Conference Organization in its meeting in Cairo in 1990, emphasized the Divine source of the human rights. Consequently, it is quite illegal and impermissible to amend these rights, cancel, violate or ignore them. As for human rights in Western thought, they are natural rights, arising from the absolute sovereignty of the human, which, according to the belief of this thought, has no sovereignty over him.

\section{References}

Abdel Karim, N. H. (2004). Human Rights Education in the Arab Universities and Its Relationship with the Students' Human Development. Educational Science Journal (Special Number). Educational Studies Institute, Cairo University, pp.304-257.

Abdel Qader, S. A. (2017). Woman's Right in Islam. Dar El-Kutub, Cairo.

Abkar, H. (2007). Brief on the Rights, Freedoms and Religious Practices. Symposium on the Human Rights in Islam between Privacy and Universality. Rabat, Morocco. Islamic Education, Science and Culture Organization (IESCO).

Agha, M. H. (2003). Role of the Faculty of Education in the Palestinian Universities in Achieving the Civil Aspects with their Students. Unpublished MA Thesis, Al-Azhar University, Gaza.

Agha, M. H. (2016). Role of the Faculty of Education in the Palestinian Universities in Achieving the Civil Aspects with their Students. Unpublished MA Thesis, Al-Azhar University, Gaza.

Al-Basheer, I. A. (1442 AH). Woman's Right between Sharia and Positive Law. In Nayef Arab Academy for Security Sciences (Published Book. Riyadh, Saudi Arabia- Nayef Arab Academy for Security Sciences.

Al-Bukhari Documented it in Blood Money Book, No. (6878).

Al-Doghmi, M. R. (1984). Espionage and Its Rules in the Islamic Law. Amman, Printing Press Workers' Cooperative Society.

Al-Faqi, A. R. M.; Imbabi, N. F. (2009). Effectiveness of a Proposed Program to Develop Awareness of the Citizenship Culture and Human Rights with the Student Teachers in History Department in the Faculty of Education, Tanta University. The $2^{\text {nd }}$ Scientific Conference: Human Rights and Social Studies Curricula, the Educational Society for Social Studies, Tanta University. Vol. 3, No. 43. pp.83-121.

Al-Farhan, I. (2001). Islamic Education between Originality and Contemporaneousness Dar Al-Furqan, Jordan.

Al-Hafeth, A. Q. B. A. (1979). History of Damascus City. Revised by Salah Eddin Al-Munajjed ( $1^{\text {st }}$ Ed), Arab Community, Damascus.

Al-Hashimi, M. A. (200o). Muslim's Personality as Formed by Islam in the Holy Quran and Sublime Sunnah. Printed Matters Agency, Riyadh.

Al-Janabi, A. S. (2015). Right of Life in Islam, Study in the Comparative Jurisprudential Rights and Sharia Rules. Teacher's Journal, Vol. 1, No. 212, pp.267-296.

Al-Jarbawi, A. (2001). Statement in the Human Rights. Referential Topic for both Male and Female Teachers, UNRWA, Department of Education, Jordan, 2001.

Al-Khaza'aleh, M. (2012). Origins and Principles of Education. Dar Safaa for Publication and Distribution.

Al-Marzouqi, I. A. (2005). Human Rights in Islam. Publications of the Cultural Community, Abu Dhabi.

Al-Motawakkil, M. (2005). Islam and the Human Rights, Human Rights Books, the Global, Islamic and Arab Views. Arab Studies Center, Beirut.

Al-Mufti, M. and Al-Wakeel, S. (1992). The Western Political Thought and the Islamic Sharia (Law). Dar Al-Nahda Al-Islamiah, Cairo.

Al-Shatibi, A. A. I. (1980). Approvals in the Fundamentals of Sharia. Beirut, Dar Al-Marfa.

Al-Shishani, A. W. (1998). Human Rights and His Basic Freedom in Islam and the Contemporary Systems. Royal Scientific Society Printing Press (Without Publishing Place).

Al-Wafi, A. (2008). Human Rights in Islam, Association of the Arab Universities Journal, No. (107), V. (20), pp.111131.

Alwan, A. (1995). Children Upbringing in Islam. Dar Esslam for Printing, Publication and Distribution, Cairo.

Atiyyah, H. (2008). Brief on the Human Rights. Jaffa Scientific House for Publishing and Distribution, Amman Jordan.

Basyouni, M. S. (2003). International Documents on Human Rights. Cairo, Egypt, Dar Al-Shorouq. 
Gazamel, S. (2009). Developing Human Rights in Higher Education in the Light of the College of Education. The $2^{\text {nd }}$ Scientific Conference on Human Rights and Social Studies Curricula. Cairo, Egypt: Ainshams

Holy Quran, Surah Al-Alaq, Verse No. 1.

Holy Quran, Surah Al-Hujurat, Verse No. 12.

Kashakesh, K. (1987). Public Freedom in the Contemporary Political Systems. Alexandria, Dar Al-Maaref.

Kilani, S. J. (2003). Human Rights Education in the Faculties of Education. Proposed Perception. Arab Education Future, Vol. 9, No. 31, pp.9-99.

Mahmoud, A. S. (1997). Biography of the Educational Thought across History. Dar Al-Shorouq. Jeddah.

Mohammad A. M. (2004) and Samehi Saleh Al-Wakeel. Human Rights in the Arab Political Thought. Dar Al-Nahda, Beirut.

Nu'man, F. A. (2018). Human Rights: Comparative Study between the Islamic Jurisprudence and the Universal Declaration of the Human Rights, Personal Study Series, Conditional Study, Cairo.

Oudeh, A. Q. (1987). Criminal legislation in Islam. Beirut. Dar Al-Kitab Al-Arabi.

Qaqeesh, S. (2005). Learn Your Rights and Teach Them. Jordanian Society for Human Rights, Jordan.

Salem, A. A. A. (200o). History of Muslims and Their Effects in Andalusia. Beirut.

Sultan, M. S., and Mujahid, A. A. M. (2008). Awareness of the Female Students of Al-Azhar University on Issues Associated with the Human Rights in Islam. Arab Education Journal, Arabic Center for Education. 321, Vol. 14, No. 54, pp.21-321.

Wade, R. C. (2002). Conceptual Change in Elementary Social Studies: Accesses Study of Fourth Graders, Understanding of Human Rights. Theory and Research in Social Education, Vol. 22. 2002, pp. 74-95.

Yousef, A. (2009). Human Rights in the Educational Life. Dar Al-Manahej for Publication and Distribution. Amman, Jordan. 